\title{
Impact of fertilizer urea on liver histopathology of fresh water snake head, Channa punctata
}

\author{
Nobonita Deb ${ }^{1}$ and Suchismita Das ${ }^{2 *}$ \\ ${ }^{1}$ Aquatic Toxicology and Remediation Laboratory, Dept. of Life Science and Bioinformatics, Assam University, Silchar, India \\ ${ }^{2}$ Aquatic Toxicology and Remediation Laboratory, Dept. of Life Science and Bioinformatics, Assam University, Silchar, India \\ *Corresponding Author: drsuchismita9@gmail.com , Tel.: 9435367192
}

Available online at: www.isroset.org

Received: 25/Jan/2019, Accepted: 10/Feb/2019, Online: 28/Feb/2019

\begin{abstract}
The widespread use of agrochemicals such as fertilizers in agricultural practices have been predicted to show adverse effects on fish, since bulk of the fertilizers sprayed on agricultural crops find way into water bodies. The effect of commonly used fertilizer, urea on histopathology of fresh water teleost fish Channa punctata was studied. The median lethal concentration after exposing fish to urea for 96 hours $\left(96-\mathrm{h} \mathrm{LC}_{50}\right.$ ) was found to be $19.75 \mathrm{gL}^{-1}$ and for the chronic toxicity tests spanning for 28 days, sublethal concentrations of urea, viz., $1.97 \mathrm{~g} \mathrm{~L}^{-1}\left(1 / 10^{\text {th }} 96-\mathrm{h} \mathrm{LC}_{50}\right)$ and $9.87 \mathrm{~g} \mathrm{~L}^{-1}\left(1 / 2\right.$ of $\left.96-\mathrm{h} \mathrm{LC}_{50}\right)$ were considered. Accordingly, two test groups having 3 replicates with 5 fish in each one were exposed to $1.97 \mathrm{~g} \mathrm{~L}{ }^{-1}$ and 9.87 $\mathrm{g} \mathrm{L}^{-1}$ urea. Control in tap water without urea was simultaneously run. After 28 days of chronic exposure fish liver samples were collected, processed, stained in Hematoxylin-Eosin and observed under light microscope for histopathological alterations. The liver of control group were normal while the fish exposed to urea showed signs of hepatic alterations such as dilation of sinusoids, vacuolation and necrosis, with severity increasing with dose. This study revealed that urea, which seems innocuous, could actually induce various histopathological anomalies in fish, posing a threat to ecosystem.
\end{abstract}

Keywords-Channa punctata, fish, histopathology, liver, urea

\section{INTRODUCTION}

The use of agrochemicals such as fertilizers, insecticides, herbicides, and fungicides has now become a vital component of modern day agricultural practices, however, the disproportionate use of these agrochemicals may lead to the problem of environmental contamination [1]. The eventual sink for many of these contaminants is the aquatic environment, either due to direct discharges or to run-offs and other processes [2]. Such anthropogenic compounds and their metabolites which contaminate aquatic ecosystems have been reported to impact on aquatic life, especially fish [3].

Urea $\left[\left(\mathrm{NH}_{2}\right)_{2} \mathrm{CO}\right]$ is the most commonly used nitrogen containing fertilizer and its utilization is escalating progressively. The use of urea as a nitrogen fertilizer and feed additive has been increased 100-fold in the past few decades in the world, with a doubling in just the past decade alone [4]. There are number of evidences which prove that urea can be transported to aquatic bodies despite a common belief that urea fertilizer is retained in soils [4]. Recently, fertilizers have been found to impact fish health by way of spray drift [5].

The sequential order of responses to pollutant stress within a biological system can be measured by using suitable biomarkers, which indicate certain biochemical or cellular modifications due to the presence and magnitude of toxicants [6]. Histological techniques have long been assumed to reflect the effects of exposure to a variety of anthropogenic pollutants [7], [8]. Hence, in the present study efforts have been made to assess the histological anomalies inflicted on liver tissues by the sublethal doses of the fertilizer urea at 28 days exposure durations in snake head, Channa punctata (Bloch), a teleost fish.

\section{Methodology}

\section{A. Maintenance of fish}

Channa punctata weighing $27.6 \pm 0.7 \mathrm{~g}$ with an average length of $14.8 \pm 0.2 \mathrm{~cm}$ was bought from a local fishery, which was free from pollutants. The fish were transferred to a large aquarium with chlorine-free tap water and acclimatized for three weeks under laboratory setting prior to experiments. Fish were nurtured with commercial fish food (Tokyu fish pellet obtained from Fish Aquarium Home, Laxmi Nagar, Delhi) two times a day. Water was changed regularly and dead animals (if any) were removed as quickly as possible. The $\mathrm{pH}$, dissolved oxygen of the water in the 
aquarium is found to be 6.5-6.7 and 6.9-7.2 $\mathrm{mgL}^{-1}$ and having temperature $23.4-25.9^{\circ} \mathrm{C}$ and electric conductivity between $81.9-84.5 \mu \mathrm{S} \mathrm{cm}^{-1}$.

\section{B. Test chemical}

Urea (46\% nitrogen, manufactured by Indian Farmers Fertilizer Co-operative limited, Ghiyanagar, Alahabad) was bought from agrochemical retailer. $\mathrm{LC}_{50}$ values for $96 \mathrm{~h}$ for urea to Channa punctatus were found to be $19.75 \mathrm{gL}^{-1}$ in a prior study as per [9] and two sublethal doses, viz., 1.97 $\mathrm{g} \mathrm{L}^{-1}\left(1 / 10^{\text {th }} 96-\mathrm{h} \mathrm{LC}_{50}\right)$ and $9.87 \mathrm{~g} \mathrm{~L}^{-1}\left(1 / 2\right.$ of $\left.96-\mathrm{h} \mathrm{LC}_{50}\right)$ were selected for chronic studies.

\section{Experimental design}

Two investigational doses of urea, and a control set were maintained for 28 days under constant aeration and renewal of entire test waters every day. For each set, there were three replicates and each replicate had 5 fish. Fish were fed twice daily with commercially available fish food. All the experiments were performed as per the Assam University, Silchar Bioethics guidelines and in compliance with the guidelines of [10].

\section{Histopathological analysis}

After 28 days of exposure, the treated as well as the control fish were anaesthetized with $1 \mathrm{mg} / \mathrm{L}$ 2-phenoxyethanol (Sigma, India) and the liver was dissected out. Small pieces of hepatic tissue were and were put in 10\% formaldehyde, embeded in paraffin wax. Various sections $(5 \mu)$ were obtained and further stained with Hematoxylin and Eosin as per standard protocol [11] and observed under a light microscope at $400 \times$ magnification (Olympus Microscope, model CX41RF with Olympus digital Camera, model: E420). A study was carried out cautiously to observe the alterations of liver anatomy.

\section{RESULTS AND DISCUSSION}

On exposure to different sublethal concentrations of urea for 28 days, the liver tissue of $C$. punctata revealed marked histopathological alterations. The tissue abrasion were detected to be more marked and rigorous with exposure to higher dose of urea $\left(9.87 \mathrm{~g} \mathrm{~L}^{-1}\right)$ which indicated that abrasions were dose dependent. No such histopathological alterations were found in the liver of control fish (Fig.1). Both the urea doses $\left(9.87 \mathrm{~g} \mathrm{~L}^{-1}\right.$ and $\left.1.97 \mathrm{~g} \mathrm{~L}^{-1}\right)$ adversely affected the liver architecture of $C$. punctata after 28 days of exposure. The most remarkable changes in the liver were vacuolar degeneration, necrosis and damage of hepatocytes. At $9.87 \mathrm{~g} \mathrm{~L}^{-1}$, the severity exaggerated with wide vacuolar degeneration, necrosis, picnotic nucleus along with damage of hepatocytes (Fig. 3) as compared to $1.975 \mathrm{~g} \mathrm{~L}^{-1}$ with less rigorous impact (Fig. 2).

\section{Discussion}

Rapid, intense agricultural development has resulted in the extensive use of fertilizers on farm-lands. Most of the nitrogenous fertilizers are not absorbed products and they make their way to both underground and surface water. Researches show that only $10-15 \%$ of applied phosphate fertilizer is absorbed by the crops, whereas the rest is lost [12]. High doses nitrogen fertilizer increases the concentration of ammonia which can toxicologically affect gill, kidney, and liver tissue structure [13]. The liver of Channa punctatus comprises of hepatic cells called hepatocyte and sinusoids. Liver histoplogy of fish have successfully established correlation between xenobiotic exposure and pathology [14]. Report suggested that contact to several types of toxicants result in puffy hepatocytes [15]. In a study conducted by [16], amphibians exposed to agricultural runoff had a higher proportion of parasitic cysts relative to controls. Reports are there that pathological changes are found in the liver and kidney of Mallards (Anas platyrhynchos) and Coots (Fulica atra), collected from fishponds in southern Poland were more severe in areas contaminated by the high extent of urban stream [17]. Although, scarce reports are available on adverse effects of fertilizers on liver of fish, it has been reported that different tissues of Channa striatus were adversely affected by fertilizer industry effluents, particularly at high sublethal application inducing noteworthy changes in the levels of protein and activity of LDH [18]. The main alterations observed in this study were extensive vacuolar degeneration and localized necrosis of fish liver, which indicated that hepatic degeneration had occurred in the exposed fish. Further, we also observed vacuolization, which were also reported in fishes exposed to toxic contaminants [19]. We also observed pycknotic or highly condensed nucleus in hepatocytes that might be attributed to the deposition of lipids and glycogen [20]. Microscopic examination of fish tissue has become a crucial tool in detecting early effects of xenobiotics on morphology [21]. This study revealed that urea, which seems innocuous, could actually induce various histopathological anomalies in fish, posing a threat to ecosystem.

\section{Conclusion ANd Future Scope}

In agricultural field use of fertilizer is a common phenomenon. Considerable growth has been made in understanding the environmental impact of urea on fish. The present analysis revealed that even after manifold dilution, urea causes deleterious hepatic damage indicative of environmental toxicity. Therefore, it is, important to protect our environment and aquatic ecosystem through good pollution managing policy and to achieve a sustainable future. More research work is necessary for further meticulous explication of effects of urea. 


\section{Figures and Tables}

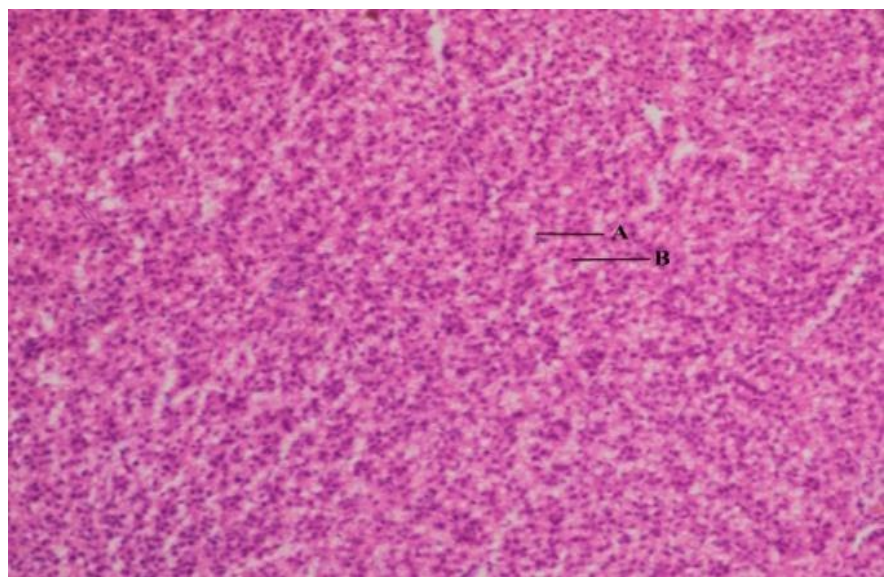

Fig 1. Transverse section of the liver of control Channa punctata after 28 days $(\times$ 400): $A=$ sinusoid, $B=$ hepatocyte.

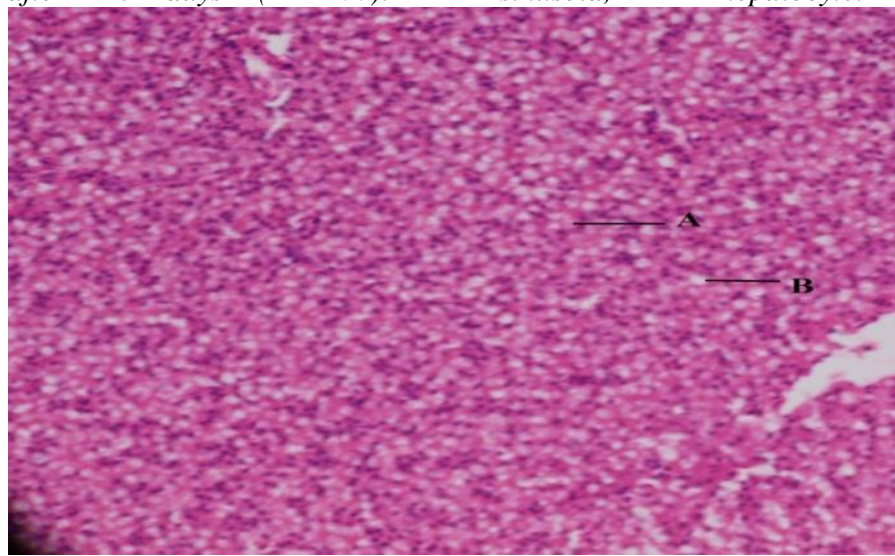

Fig.2. Transverse section of the liver of Channa punctata after 28 days of exposure to $1.97 \mathrm{~g} \mathrm{~L}^{-1}(X 400):(A)=$ focal necrosis, $(B)=$ vacuolar degeneration.

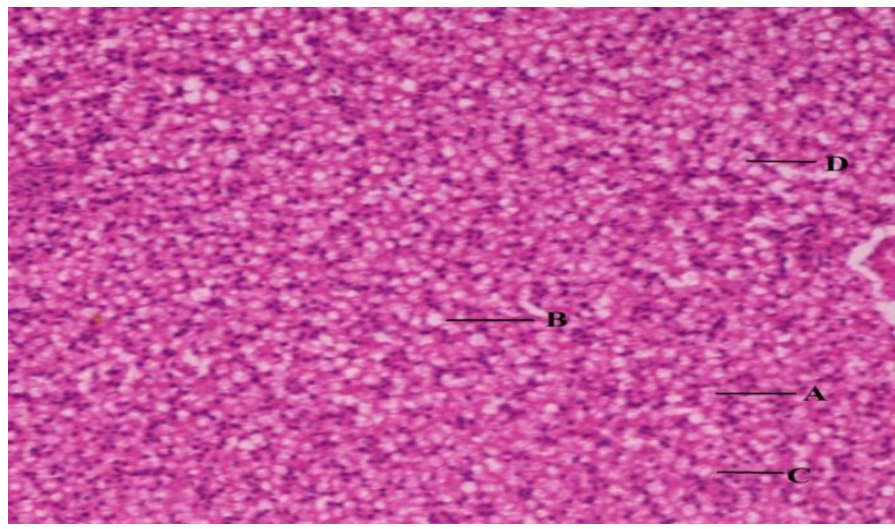

Fig 3. Transverse section of the liver of Channa punctata after 28 days of exposed to $9.87 \mathrm{~g} \mathrm{~L}^{-1}(\times 400):(A)=$ focal necrosis, $(B)=$ extensive vacuolar degeneration, $(C)=$ piknotic nucleus and $(D)=$ damage of hepatocyte.

\section{ACKNOWLEDGMENT}

We thank the Biotech Hub, Life Science, Assam University for light microscopy facility.

\section{REFERENCES}

[1] D. Despommier, "The rise of vertical farms" Sci. Am. Vol. 301, pp. 60-67. 2009.

[2] J.J. Stegeman, M.E. Hahn, Biochemistry and molecular biology of monooxygenase: current perspective on forms, functions, and regulation of cytochrome P450 in aquatic species. In: Malins, D.C., Ostrander, G.K. (Eds.), Aquatic toxicology; Molecular, Biochemical and Cellular Perspectives. Lewis Publishers, CRC press, Boca Raton, pp. 87-206. 1994.

[3] I. Altinok, E. Capkin, "Histopathology of rainbow trout exposed to sublethal concentrations of methiocarb or endosulfan", Toxicol. Pathol. Vol. 35, pp. 405-410. 2007.

[4] P.M. Glibert, J. Harrison, C. Heil, S. Seitzinger, "Escalating worldwide use of urea - a global change contributing to coastal eutrophication. Biogeochemistry," Vol. 77, pp. 441-463. 2006.

[5] V. Palanivelu, K. Vijayavel, S. Ezhilarasibalasubramanian, M.P. Balasubramanian, "Impact of fertilizer (urea) on oxygen consumption and feeding energetic in the fresh water fish Oreochromis mossambicus," Environ. Toxicol. Pharmacol. Vol.19, pp. 351-355. 2005.

[6] NRC: Committee on Biological Markers of the National Research Council, Biological markers in environmental health research. Environ. Health Perspect. Vol. 74, pp. 3-9. 1987.

[7] R.J. Roberts, Fish Pathology. W.B. Saunders, Philadelphia. 2001.

[8] I. Riba, J.Blasco, N. Jime'nez-Tenorio, M.L. Gonza' lez de Canales,T. Angel DelValls, "Heavy metal bioavailability and effects: II. Histopathology-bioaccumulation relationships caused by mining activities in the Gulf of Cadiz (SW,Spain)", Chemosphere, Vol.58, pp. 671-682. 2005.

[9] D. Finney, Probit analysis, pp. 333. 1971.

[10] OECD (Organization for Economic Cooperation and Development), Guideline For The Testing of Chemicals: Fish, Acute Toxicity Test, No. 203. 1992.

[11] S. Das, A. Gupta, "Effects of cadmium chloride on oxygen consumption and gill morphology of Indian flying barb, Esomus danricus." J environ boil, Vol. 33, 1057-1061. 2012.

[12] E. Bulut, A. Aksoy, "Impact of fertilizer usage on phosphorus loads to Lake Uluabat. Desalination," Vol. 226, pp. 289 - 297. 2008.

[13] A.C. Benli, G. Koksal, A. Ozkul, "Sublethal ammonia exposure of Nile tilapia (Oreochromis niloticus L.): effects on gill, liver and kidney histology," Chemosphere, Vol. 72, pp. 1355-1358. 2008.

[14] R.T. Di Giulio, D.E. Hinton, The Toxicology of Fishes. CRC Press Taylor \& Francis Group, London, pp. 370-380. 2008.

[15] E. Agamy, "Histopathological liver alterations in juvenile rabbit fish (Siganus canaliculatus) exposed to light Arabian crude oil, dispersed oil and dispersant," Ecotoxicol. Environ. Saf. Vol. 75, pp. 171 - 179. 2012.

[16] J. Kiesecker, "Synergism between trematode infection and pesticide exposure: a link to amphibian limb deformities in nature," Proc Natl Acad Sci USA, Vol. 99, pp. 9900-9904. 2002.

[17] L.J. Binkowski, K. Sawicka-Kapusta, J. Szarek, E. Strzy żewska, M. Felsmann, "Histopathology of liver and kidneys of wild living Mallards Anas platyrhynchos and Coots Fulica atra with considerable concentrations of lead and cadmium," Sci. Total Environ., Vol. 450 - 451, pp. 326 - 333. 2013.

[18] Y. Archana, G. Anita, S. P Ravi, K. R. Devendra, S. Bechan, "Fertilizer Industry Effluent Induced Biochemical Changes in 
Fresh water Teleost, Channa striatus (Bloch)." Bull Environ Contam Toxicol. Vol. 79, pp. 588-595. 2007.

[19] W.B. Ameur, J. de Lapuente, Y.EI. Megdiche, B. Barhoumi, S. Trabelsi, L. Camps, J. Serret, D. Ramos-L, J. Gonzalez-Linares, M.R. Driss, M. Borràs, "Oxidative stress, genotoxicity and histopathology biomarker responses in mullet (Mugil cephalus) and sea bass (Dicentrarchus labrax) liver from Bizerte Lagoon (Tunisia)," Mar. Pollut. Bull.Vol. 64, pp. 241-251. 2012.

[20] H. Liu, P. Sun, H. Liu, S. Yang, L. Wang, Z. Wang, "Hepatic oxidative stress biomarker responses in freshwater fish Carassius auratus exposed to four benzophenone UV filters," Ecotox Environ Safe, Vol. 119, pp. 116-122. 2015.

[21] F.A. Guardiola, A. Cuesta, J. Meseguer, S. Martinez, M.J. Martinez-Sanchez, C. PerezSirvent, M.A. Esteban, "Accumulation, histopathology and immunotoxicological effects of waterborne cadmium on gilthead seabream (Sparus aurata)," Fish Shellfish Immun. Vol. 35, 792-800. 2013.

\section{AUTHORS PROFILE}

Nobonita Deb pursued M.Sc., in Life Science (Zoology) from Assam University (AUS), Silchar 2011. She is a research scholar in Department of Life Science since 2012, Assam University, Silchar, India.

Suchismita Das, M.Sc in Zoology, Banaras Hindu University (2004); Ph.D in Environmental Science, Assam University (2011); Post-doctorate, University of Florida, Gainesville, USA (2016-2017). She is currently working as Assistant Professor in Department of Life Science \& Bioinformatics, Assam
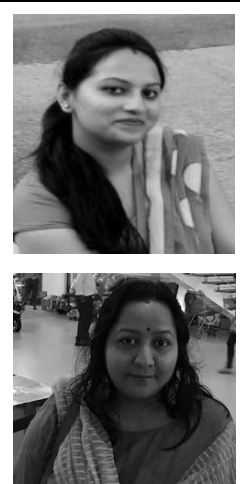
University, Silchar (India) since 2005. She has published more than 70 research papers in reputed international journals including Thomson Reuters (SCI \& Web of Science) and attended several conferences of national and International repute. Her main research work focuses on aquatic toxicology and remediation. 